\title{
Evaluation of Some Physicochemical Properties and Heavy Metals in Post-Treated Produced Water from Offshore Locations in the Niger Delta Area, Nigeria
}

\author{
${ }^{* 1}$ ONYEMA, HK; IWUANYANWU, ${ }^{2} \mathrm{JO}$; EMEGHARA, ${ }^{3}$ GC \\ ${ }^{1,2,3}$ Department of Maritime Management Technology \\ ${ }^{1,2,3}$ Federal University of Technology Owerri
}

\begin{abstract}
This study evaluated the physiochemical properties of produced water. The effective management of offshore $\mathrm{E} \& \mathrm{P}$ wastes is one of the challenges facing the oil and gas industry in Nigeria. Sampling points were carefully selected to obtain samples that are truly representatives of the post-treated produced water. The $\mathrm{pH}$ of the recipient marine water showed compliance with the DPR(Department of Petroleum Resources) standards unlike that of the produced water with a mean value of 6.33.The study concludes with the recommendation that the provisions of Environmental Guidelines and Standard for the Petroleum Industry (EGASPIN ) should be followed strictly to facilitate effective management of offshore E\&P wastes in Nigeria as it is not in line with contemporary international standards as most of the parameters tested and analyzed are not within limit. @ JASEM
\end{abstract}

http://dx.doi.org/10.4314/jasem.v19i4.25

\section{Introduction}

The regulation of offshore oil and gas activities in Nigeria is within the legislative competence of the federal government because mines and minerals, including oil fields, oil mining, geological surveys and natural gas are listed in the exclusive legislative list of the Nigerian Constitution (Constitution of the Federal Republic of Nigeria, 1991). Although several environmental laws deal with waste management and pollution abatement, they are generally outdated, limited in scope or not directly applicable to offshore oil and gas activities. For instance, the National Environmental Standards and Regulations Enforcement Agency Act 2007 (hereafter NESREA Act) empowers NESREA, amongst other things, to enforce compliance with regulations on the handling and disposal of hazardous chemicals and waste except in the oil and gas sector (NESREA Act, 2007). As a result, the NESREA Act, which is the foremost environmental legislation in Nigeria, excludes the oil and gas industry from its scope of application. In addition, the Harmful Waste (Special Criminal Provisions, etc) Act 2004 makes it a crime to dispose of any harmful waste in any land or territorial waters, contiguous zone, exclusive economic zone (EEZ) or inland waterways of Nigeria but makes no mention of offshore waters (Harmful Waste 2004). Furthermore, the National Effluent Limitation Regulations of 1991 contains effluent limitations for the discharge of E\&P wastes into inland waters and so it is not applicable to the offshore oil and gas industry. Consequently, the offshore oil and gas waste management regime is inert as there is currently no specific law regulating offshore E\&P waste management in Nigeria.
Nonetheless, Environmental Guidelines and Standard for the Petroleum Industry (EGASPIN) contains effluent limitations, standards and procedures for evaluation and monitoring of the discharge of different types of E\&P wastes into the environment. DPR is responsible for administering and ensuring compliance with the provisions of EGASPIN.

The interplay of the crude oil and petroleum products as well as the associated waste with the environment must be checked through the regulations in other to prevent avoidable calamities on human population. In Nigeria, the necessary regulations and guidelines to protect and/or restore the environment to as near perfect as possible, if damage does occur in the petroleum Industry it rest squarely on the Department of Petroleum Resources (DPR).However in terms of implementation or actual restoration of the damaged environment, Nigerian regulation states that licensee/lessee or the operator is expected to be responsible for hazardous materials, wastes and toxic chemicals removed from cradle to grave. The paper sets to assess the performance of DPR in the regulatory activities towards the cleanliness of the environment especially on the marine environment as the operators can only perform their duties when properly guided by DPR. In other words is DPR carrying out its regulatory functions efficiently and effectively?

The aim of this study was to evaluate the physicochemical properties and constituents of post treated produced water from selected offshore locations in 
the Niger Delta to determine the extent of compliance with standards and global best practices in their treatment and their suitability for offshore disposal and impact of its disposal in the recipient water

Research Hypotheses: The following hypotheses will be tested;

$\mathrm{H}_{01}$ : Oil/grease content of effluent water discharge by exploration companies in Nigeria is not within DPR and International standards.

$\mathrm{Ho}_{2}$ : Chloride content of Post treated Produced water discharge in Nigeria is not within acceptable standard by DPR.

\section{MATERIALS AND METHODS}

Sampling points were carefully selected to obtain samples that are truly representatives of the posttreated produced water. Grab samples were collected with sterile 1000 liters Wheaton glass bottles from flowing effluent at the point of final discharge to the receiving water, this was done at an interval of two weeks. In-situ analyses of unstable parameters such as $\mathrm{pH}$, conductivity, and total dissolved solid, were done with the aid of portable field equipment. DspH3 , pH/conductivity meter, YSI 550A dissolved oxygen meter and Gun-type infra-red thermometer. All laboratory analyses were carried out according to standard methods as described in EGASPIN (2002) and ASTM (2002). These were used without modifications for the relevant analyses. In addition, all laboratory procedures were adequately standardized and all instruments appropriately calibrated. The following parameters were analyzed for: turbidity, TSS, THC, BOD, COD, Salinity and trace metals.

Samples of produced water were obtained from three flow stations: X (onshore), Y (Swamp) Z (offshore) and two terminals (near shore) in the Niger Delta. Measurement of temperature and $\mathrm{pH}$ were done at the sampling point due to sensitivity of their values, while the analysis of other parameters was done in the laboratory.

For $\mathrm{pH}$, the $\mathrm{pH}$ meter was standardized with buffer solution and calibrated before measurement. For Turbidity, the Jackson candle turbid-meter was set up. Sample was poured from a measuring cylinder into the calibrated glass tube of the turbid-meter. The beam of light from the candle was then observed until the samples cloudiness impelled the light. The reading on the glass tube was done and converted into Jackson candle units.

\section{RESULTS AND DISCUSSION}

Produced Water: Results of the analyses of the physico-chemical properties of produced water are shown in Table 1. The $\mathrm{pH}$ (6.25-6.40), chloride $(15,679-16,334.21 \mathrm{mg} / \mathrm{l})$ and total dissolved solidsTDS $(31,400.00-31,430 \mathrm{mg} / \mathrm{l})$. These did not meet the DPR standards for disposal offshore and therefore requires further treatment to bring these parameters within allowable limits.

Recipient Water : Results of the analyses or the physico-chemical parameters of the recipient marine water from five designated points to the effluent plant (North, South, Central, East and West), is shown in the Table below

Table 1

\begin{tabular}{lllllll}
\hline Parameters & Units & North & South & Central & East & West \\
\hline pH & OC & 8.14 & 8.20 & 7.41 & 8.27 & 8.35 \\
Temperature & ms/cm & 29.3 & 29.3 & 30.2 & 29.5 & 29.0 \\
Conductivity & mg/L & 34.1 & 33.9 & 40.0 & 34.2 & 43.7 \\
THC & mg/L & $<0.01$ & $<0.01$ & 0.10 & 0.03 & $<0.001$ \\
TOC & mg/L & 5.43 & 5.50 & 6.91 & 5.11 & 5.0 \\
DOC & mg/L & 4.8 & 4.6 & 4.0 & 4.9 & 5.2 \\
BOD & mg/L & 46.2 & 47.11 & 60.1 & 47.04 & 47.0 \\
COD & mg/L & 60.18 & 59.39 & 72.01 & 61.0 & 61.41 \\
TDS & mg/L & 36,337 & 36,300 & 36,500 & 36,50 & 36,400 \\
Chloride & mg/L & 20,105 & 20,110 & 21,420 & 20,218 & 20,228 \\
Nitrogen & mg/L & 1.400 & 1.404 & 1.300 & 1.355 & 1.326 \\
Phosphorous & mg/L & 0.035 & 0.042 & 0.050 & 0.046 & 0.040 \\
Arsenic & mg/L & 0.002 & 0.003 & 0.004 & 0.0002 & 0.001 \\
Lead & mg/L & $<0.001$ & $<0.001$ & 0.003 & 0.001 & 0.001 \\
Zinc & mg/L & 0.230 & 0.220 & 0.225 & 0.226 & 0.215 \\
Chromium & mg/L & $<0.001$ & $<0.001$ & 0.008 & $<0.001$ & $<0.001$ \\
Vanadium & MPN/100Ml & $<0.001$ & $<0.001$ & $<0.001$ & $<0.001$ & $<0.001$ \\
E-coil & & 37.00 & 41.00 & 56.0 & 41.00 & 38.00 \\
& & & & & & \\
\hline
\end{tabular}

Source: Field Work

${ }^{*}$ ONYEMA, HK; IWUANYANWU, ${ }^{2} \mathrm{JO}$; EMEGHARA, ${ }^{3} \mathrm{GC}$ 
Table 2. The DPR standard for Produced Water Discharge

\begin{tabular}{lll}
\hline Parameters & Unit & $\begin{array}{l}\text { DPR } \\
\text { Limit }\end{array}$ \\
\hline Date sampled & & \\
pH & & $6.5-8.5$ \\
Temperature & & 30.0 \\
THC & $\mathrm{mg} / \mathrm{L}$ & 40.0 \\
Chloride & $\mathrm{mg} / \mathrm{L}$ & 2000.0 \\
Turbidity & $\mathrm{mg} / \mathrm{L}$ & 15.0 \\
TDS & $\mathrm{mg} / \mathrm{L}$ & 5000.0 \\
TSS & $\mathrm{mg} / \mathrm{L}$ & 50.0 \\
COD & $\mathrm{Mg} / \mathrm{L}$ & 125.0 \\
BOD & $\mathrm{Mg} / \mathrm{L}$ & 125.0 \\
Lead & $\mathrm{Mg} / \mathrm{L}$ & \\
Copper & $\mathrm{Mg} / \mathrm{L}$ & \\
Chromium & $\mathrm{Mg} / \mathrm{L}$ & 0.5 \\
Zinc & $\mathrm{Mg} / \mathrm{L}$ & 5.0 \\
\hline
\end{tabular}

Source: DPR 1991

Table 3.The Physical, Chemical, and Biological Characteristics of the Post -treated Produced Water

\begin{tabular}{llllll}
\hline Parameters & Unit & Week 1 & Week 2 & Mean & SD \\
& & & & & \\
Date sampled & & $19 / 07 / 14$ & $27 / 07 / 14$ & 6.33 & 0.11 \\
$\mathrm{pH}$ & - & 6.25 & 6.40 & 29.75 & 0.36 \\
Temperature & $\mathrm{OC}$ & 29.50 & 13.75 & 15.16 & 3.05 \\
THC & $\mathrm{mg} / \mathrm{L}$ & 17.31 & $16,334.21$ & $16,006.81$ & 463.02 \\
Chloride & $\mathrm{mg} / \mathrm{L}$ & $15,679.40$ & 11.00 & 10.85 & 0.9 \\
Turbidity & $\mathrm{mg} / \mathrm{L}$ & 10.70 & $31,400.00$ & $31,415.00$ & 21.21 \\
TDS & $\mathrm{mg} / \mathrm{L}$ & $31,430.00$ & 12.00 & 11.00 & 1.41 \\
TSS & $\mathrm{mg} / \mathrm{L}$ & 10.0 & 92.10 & 93.72 & 2.28 \\
COD & $\mathrm{Mg} / \mathrm{L}$ & 95.33 & 64.30 & 62.78 & 2.16 \\
BOD & $\mathrm{Mg} / \mathrm{L}$ & 61.25 & 0.002 & 0.003 & 0.001 \\
Lead & $\mathrm{Mg} / \mathrm{L}$ & 0.004 & 0.659 & 0.645 & 0.021 \\
Iron & $\mathrm{Mg} / \mathrm{L}$ & 0.630 & 0.077 & 0.080 & 0.005 \\
Copper & $\mathrm{Mg} / \mathrm{L}$ & 0.084 & 0.007 & 0.006 & 0.001 \\
Chromium & $\mathrm{Mg} / \mathrm{L}$ & 0.005 & 0.173 & 0.170 & 0.005 \\
Zinc & $\mathrm{Mg} / \mathrm{L}$ & 0.166 & & & \\
\hline
\end{tabular}

Source: Field work

Total Hydrocarbon Content, THC (13.00-17.31mg/l), turbidity $(10.70-11.00 \mathrm{mg} / \mathrm{l})$, total suspended solids, TSS (10.00-12.00mg/l), and temperature (29.50$29.75 \mathrm{oC}$ ), all fall within the DPR allowable limits and therefore do not constitute any treat to the recipient marine environment. This was also the case of the chemical oxygen demand, COD (92.10$95.33 \mathrm{mg} / \mathrm{l})$, biochemical oxygen demand, BOD $(61.25-64.30 \mathrm{mg} / \mathrm{l})$, and heavy metals of lead, iron, copper, chromium, and zinc. The $\mathrm{pH}$ of the recipient marine water showed compliance with the DPR standards unlike that of the produced water with a mean value of 6.33 . The central discharge point with a $\mathrm{pH}$ value of 7.41 indicates the point maximum concentration of the effluent discharge thereby having a near neutral $\mathrm{pH}$. The total hydrocarbon concentration (THC) was $0.1 \mathrm{mg} / \mathrm{l}$ at the central discharge point. The dissolved oxygen content (DOC) values show a non-compliance with DPR standards. The total dissolved solid (TDS) also show a level of non-compliance with DPR standards.

Other parameters such as nitrate, ammonium ion, cyanide, phosphate, phenols, E. coli, and trace metals showed compliance with DPR standards.

In all the physico-chemical parameters evaluated, the central discharge point showed slight variations in value showing that this was the point of maximum concentration before dilution with distance from the discharged point.

It is obvious that produced water have potential impacts on the recipient environment depending on where it is being discharged. For example, discharges to small streams are likely to have a larger environmental impact than discharges made to the open ocean by virtue of dilution that takes place

${ }^{* 1}$ ONYEMA, HK; IWUANYANWU, ${ }^{2} \mathrm{JO} ; \mathrm{EMEGHARA},{ }^{3} \mathrm{GC}$ 
there. Therefore, it can be concluded that the result is significant and that the Oil/grease content of effluent water discharge by exploration companies in Nigeria is not within DPR and International standards. Therefore, it can be concluded that the result is significant and that the Chloride content of Post treated Produced water discharge in Nigeria is not within acceptable standard by DPR.

Conclusion: Based on the results of this research, it can be concluded that Produced water discharged into the environment in the Niger Delta is yet to meet set standards for disposal as concentration of oil/grease content, total dissolved solids, total suspended solids and some other parameters are still very high, above the stipulated standard. There are laws, guidelines and regulations for the management of produced water in Nigerian oil and gas operations. However, they do not include regulations aimed at further reducing discharges in an on-going basis until zero discharge is achieved in the long term.

\section{REFERENCES}

Department of Petroleum Resources (DPR). 1998. "Environmental Guidelines and Standards for the Petroleum Industry in Nigeria". DPR: Lagos, Nigeria.

Edward Salter and John Ford, (2001). 'Holistic Environmental Assessment and Offshore Oil Field Exploration and Production', 42/1 Marine Pollution Bulletin 45
EGASPIN, (2002) Environmental Guidelines and Standards for Petroleum Industry in Nigeria 4. Petroleum Decree s.9 (1) (b)

Emeseh Engobo, (2004), 'The Limitations of Law in Promoting Synergy between Environment and Development Policies in Developing Countries: A Case Study of the Petroleum Industry in Nigeria' at 7 , available at

http://userpage.fuberlin.de/ffu/akumwelt/bc2004/do wnload/emesehf.pdf.

Environmental Guidelines and Standards for the Petroleum Industry in Nigeria (EGASPIN), revised edition 2002, issued by the Department of Petroleum Resources (DPR)

Okoro, C.C., (2002). "Microbiological Impacts of Produce Water Discharges in Nearshore Shallow Marine Water near Chevron's Escravos Tank Farm, Nigeria": African Journal of Microbiology Research. 4(13):1400-1407.

Oyalami D.O. (2008), Offshore Decommissioning in Nigeria: the Search for a Regulatory Framework, LL.B Research Project, Faculty of Law, University of Lagos, 